\title{
A RELIGIOSIDADE POPULAR E A IGREJA NA CANÇÃO LATINO-AMERICANA: UMA ANÁLISE DA CONTRIBUIÇÃO DE VIOLETA PARRA
}

Maurício Marques Brum é mestrando no Programa de Pós-Graduação em História na Universidade Federal do Rio Grande do Sul (UFRGS). E-mail: mauribrum@gmail.com

Camila Marchesan Cargnelutti é mestranda no Programa de Pós-Graduação em Letras - Estudos Literários na Universidade Federal de Santa Maria (UFSM-RS). E-mail: camila.m.cargnelutti@gmail.com

\section{Resumo}

Situando a obra de Violeta Parra dentro de uma tradição de questionamentos ao clero no cancioneiro popular latino-americano, este artigo analisa a canção Porque los pobres no tienen, considerada a primeira composição em que Violeta explicitamente critica as instituições católicas. É possível observar uma forte crítica à Igreja institucionalizada, enquanto, por outro lado, há uma tentativa de aproximação com a religiosidade popular.

\begin{abstract}
Placing Violeta Parra's work within a Latin American tradition of questioning the clergy in popular music, this paper analyzes the song Porque los pobres no tienen, considered the first composition in which Violeta Parra explicitly criticizes well-known Catholic institutions. It is possible to appreciate a strong criticism towards the institutionalized Church, while, on the other hand, there is an attempt to approach with popular religiosity.
\end{abstract}

\section{1) Violeta Parra, precursora da Nova Canção Chilena}

Nascida na província de Nubble, no sul do Chile, em 1917, Violeta Parra dedicouse a partir da década de 1950 a pesquisar e recompilar o folclore do interior de seu país, particularmente em seu aspecto musical, realizando um levantamento de instrumentos, letras e ritmos aos quais se havia acostumado durante a infância. Incentivada por um de seus irmãos mais velhos, o poeta Nicanor Parra, Violeta passou a percorrer - às vezes munida de um gravador portátil que obtivera numa viagem à Polônia - os povoados semiesquecidos das diferentes regiões do Chile. Sua rotina de trabalho, relembrada na memória do filho Ángel Parra, Violeta se fue a los cielos (2006) ${ }^{1}$, incluía longas conversas com as pessoas mais velhas dos pueblos de província que visitava. Tratava-se dos indivíduos que mais guardavam recordações dos versos ancestrais, outrora preservados pela tradição oral e agora cada vez mais ameaçados de cair no esquecimento por conta das novas formas de entretenimento em ascensão, como as músicas difundidas pelo rádio.

A recuperação realizada por Violeta Parra e por outros folcloristas da mesma época, tais como Margot Loyola (que realizou um notável trabalho, sobretudo em relação às danças típicas e ao folclore da região de Chiloé), ajudou a reacender o interesse do público e da mídia pelos ritmos tradicionais chilenos, que ganharam mais destaque ao longo da década de 60. A importância de Violeta, no entanto, não se restringiu à busca de canções ancestrais que naquela altura só eram recordadas por poucos: manifestou-se também na grande influência que ela exerceu sobre outros cantores e compositores de seu tempo, os quais deram sequência ao seu legado após sua morte, em 1967. Sem interpretar o folclore como algo estático ou uma "peça de museu",

\footnotetext{
${ }^{1}$ Publicado originalmente em 2006, Violeta se fue a los cielos foi adaptado para o cinema em 2011, em filme de mesmo nome, dirigido por Andrés Wood.
} 
Parra procurou utilizar os ritmos e instrumentos tradicionais para elaborar novas canções autorais, cujas letras, ademais, frequentemente vinham acompanhadas de uma bem marcada mensagem de cunho social:

[Violeta Parra] se compromete con los pueblos que va conociendo, no solo en cuanto poseedores de una memoria que le urge preservar, sino como personas, comunidades, que tienen reivindicaciones presentes por las que es urgente reclamar. Violeta Parra no se dedica a rescatar antigüedades congelando el movimiento incesante de la cultura popular en cuadros típicos. Desecha el folclore de postal turística y la intrusión snob. El asunto es más serio y profundo. También es político (MONTEALEGRE, 2011, p. 100).

Essa tentativa de mesclar a raiz folclórica com letras engajadas politicamente influenciaria uma geração de músicos no Chile - incluindo nomes como os filhos de Violeta Parra, Ángel e Isabel, bem como Víctor Jara, Patricio Manns, Rolando Alarcón, Osvaldo Rodríguez, Payo Grondona, os conjuntos Quilapayún e Inti-Illimani, entre outros - que se identificariam com um movimento posteriormente denominado Nueva Canción Chilena. Pelo estilo de suas músicas e por seu pioneirismo, Violeta costuma ser considerada a fundadora do que viria a ser a Nova Canção. O batismo do movimento, entretanto, ocorreria somente após a sua morte: o nome apareceria apenas em 1969, durante um festival organizado em Santiago pela Universidade Católica para discutir os rumos da música do país, mais de dois anos após o suicídio de Violeta Parra.

Mesmo que o nome do movimento não existisse, muitas das características normalmente associadas à Nova Canção Chilena podem ser identificadas na obra da artista. Para Fernando Barraza (1972):

\section{La Nueva Canción Chilena tiene características musicales y temáticas:}

1- Musicalmente, toma ritmos folklóricos o se basa en ellos para su forma expresiva (cueca, refalosa, cachimbo, trote, tonada, polca, etc). Naturalmente, usa también de preferencia instrumentos adecuados a esos ritmos (quena, charango, guitarra, guitarrón, rabel, bombo, tormento, etc).

2- Desde el punto de vista temático, alcanza tal vez su característica esencial. La letra apunta, abierta o sutilmente, hacia un cuestionamiento crítico de la sociedad, del orden establecido. Traduce, interpreta o pretende reflejar la realidad de la sociedad chilena de hoy y los distintos fenómenos que se manifiestan en ella (BARRAZA, 1972, s.p.).

Nessa busca por traduzir, interpretar ou refletir a realidade ao mesmo tempo em que se fazia um questionamento crítico da situação vivida, intenção artística corroborada também por Luis Advis (2012), distintos fenômenos foram evocados pelo cancioneiro do período. Os intérpretes da Nova Canção, deste modo, cada vez mais aproximaram seu discurso dos posicionamentos defendidos pelos partidos de esquerda, dos quais muitas vezes eram militantes ativos. Temas como a desigualdade econômica, a repressão policial contra mobilizações populares contrárias ao governo, as passeatas 
estudantis, as greves, os movimentos de pobladores $^{2}$, a exploração do trabalho de operários e campesinos, o anseio de denunciar e levantar-se contra o imperialismo norte-americano, ajudavam a compor o universo de temas presentes nas músicas de Violeta Parra e de artistas contemporâneos a ela. Nesse contexto, também é recorrente, e constitui o foco de análise deste artigo, a contraposição entre a religiosidade popular e a Igreja, demarcando uma oposição ao aparente distanciamento da instituição católica em relação às mazelas sociais e a um suposto alinhamento dessa institucionalidade com os setores dominantes e conservadores da sociedade.

\title{
2) A religiosidade popular e a institucional: uma dicotomia?
}

Como argumenta Marisol García, a obra de Violeta Parra pode ser considerada pioneira na medida em que se propõe a "ubicar en la mira de su disparo poético a sacerdotes y sumos pontífices, blancos de crítica impensables en la canción chilena hasta entonces" (GARCÍA, 2013, p. 37). Os primeiros questionamentos mais mordazes de Violeta à Igreja aparecem em duas letras datadas do início da década de 1960: Porque los pobres no tienen, composta originalmente em 1962, e ¿Qué dirá el Santo Padre?, escrita no ano seguinte. Violeta pode ter sido uma das primeiras, no Chile, a gravar uma canção com críticas explícitas ao clero e às instituições católicas, mas a temática não era exatamente nova. Posicionamentos similares já se faziam presentes em canções mais antigas, pertencentes à tradição popular e transmitidas oralmente. É necessário situar os questionamentos fortalecidos nos anos 60 -e presentes na obra de Violeta Parra - dentro dessa tradição de crítica artística à atuação da Igreja e de seus membros, que podia ser observada tanto no cancioneiro popular do Chile quanto naquele de outros países da América Latina.

Ainda no século XIX, em Sociabilidad Chilena (1844), um ensaio que chegou a ser recolhido e queimado pelo governo por seu tom fortemente anticlerical, o intelectual chileno Francisco Bilbao já registrava versos que identificou como a "expresión plebeya" da insatisfação do povo com membros do clero:

\author{
El cura no sabe arar \\ Ni sabe enyugar un buey. \\ Pero por su propia ley \\ Él cosecha sin sembrar. \\ Él para salir a andar \\ Poquito o nada se apura. \\ Tiene su renta segura, \\ Sentadito descansando, \\ Sin andarse molestando, \\ Nadie gana más que el cura (BILBAO, 1844, p. 68).
}

\footnotetext{
${ }^{2}$ Trabalhadores sem-teto, vindos para a cidade em consequência do êxodo rural, que ocupavam terrenos na periferia, organizando-se em comunidades conhecidas como poblaciones, espécies de favelas.
} 
Mesmo que as canções populares incorporassem versos amiúde críticos à Igreja na virada do século XX, como registrou de forma extensa Maximiliano Salinas Campos (2005), esse tipo de opinião raramente conseguia vencer as censuras e autocensuras do circuito comercial, daí o choque de aparente novidade provocado no público quando as gravações de Violeta Parra começaram a circular nas emissoras de rádio. Como os discos de Violeta começavam a mostrar, a década de 60 abriu - ainda que timidamente - um espaço de difusão antes impensável para esse tipo de material. As antigas coplas registradas por Bilbao em 1844, por exemplo, continuariam relativamente conhecidas, mas só seriam gravadas pela primeira vez cento e vinte e cinco anos mais tarde, em 1969, pelos filhos de Violeta Parra - ainda assim, a produção do disco de Ángel e Isabel ocorreu em uma gravadora independente ${ }^{3}$.

Convém destacar que a primeira metade da década de 1960, quando saem as músicas inquiridoras de Violeta, é também marcada por um processo de revisão de posicionamentos dentro da própria Igreja. São os anos das discussões do Concílio Vaticano II, no que as lideranças católicas ensaiam um repensamento de seu papel e de sua atuação na sociedade. João Batista Libanio comenta que o Concílio acabaria tendo uma "orientação progressista" que muitos não imaginavam no momento de sua convocação, no final de 1961, criando um clima de "abertura a novas experiências, valorizando assim os anseios do sujeito moderno" (LIBANIO, 2005, p. 84). Para Ney de Souza, o Vaticano II trouxe, de fato "oportunidades de se traçar um caminho alternativo", mas, por outro lado, "frustrou ao não colocar no centro dos debates questões que não são só latino-americanas, mas mundiais: o empobrecimento da população e as expectativas dos fiéis católicos de uma Igreja inserida diretamente no mundo, dialogando" (SOUZA, 2005, p. 34). Na América Latina, as discussões internas da Igreja sobre os caminhos a seguir levariam, em 1968, à realização da Segunda Conferência do Episcopado Latino-Americano, na Colômbia, onde ganharam força doutrinas progressistas como aquelas defendidas pela Teologia da Libertação.

A autocrítica que a Igreja procurava fazer em suas reuniões internas, particularmente, no caso latino-americano, a de 1968, de certa forma respondia aos questionamentos crescentemente audíveis que vinham sendo feitos pela sociedade, manifestando-se também em suas produções artísticas. Na mesma época em que Violeta Parra desenvolvia seu trabalho no Chile, em outras nações do continente algumas composições com temáticas semelhantes começavam a ser editadas pelas gravadoras locais e, embora ainda não alcançassem muito destaque no circuito comercial, permitiam uma difusão muito maior do que a existente até ali. Com o aparecimento dessas novas gravações, tornava-se cada vez mais nítida a forma como esses autores identificados politicamente com a esquerda encaravam a questão religiosa: se por um lado buscavam compreender a religiosidade do povo para quem cantavam, raramente deixavam de questionar a atuação de setores mais conservadores do clero.

\footnotetext{
${ }^{3}$ Uma versão modificada de alguns dos versos registrados por Francisco Bilbao apareceria na primeira faixa do disco La Peña de los Parra, vol. I, sob o título Coplas folklóricas, com autoria apócrifa (a música foi identificada apenas como "popular chilena"). O long-play foi editado em 1969 pelo selo independente da Peña de los Parra e continha também canções populares venezuelanas e composições de Violeta Parra.
} 
$\mathrm{Na}$ vizinha Argentina, o cantor e compositor Atahualpa Yupanqui desenvolvia um trabalho análogo ao de Violeta, de recompilação folclórica e criação artística autoral, investindo em temáticas similares. Duas canções suas que se tornaram muito conhecidas nesse momento alinham-se precisamente ao movimento que tencionava demonstrar preocupação social e manifestá-la através da música, desembocando também em discursos com tom crítico à Igreja:

\begin{abstract}
Con escritos como "Coplas del payador perseguido" ("he visto tanta pobreza,/ que yo pensé con tristeza:/ Dios por aquí no pasó") y "Preguntitas sobre Dios" ("que Dios vela con los pobres/ tal vez sí o tal vez no/ pero es seguro que almuerza en la mesa del patrón"), el argentino había conseguido mostrar una voz insumisa a la jerarquía católica, y acorde a los movimientos de liberalización y mayor compromiso social entonces al interior de esa propia Iglesia (GARCÍA, 2013, p. 37).
\end{abstract}

Como observou Bernardo Guerrero (1994, p. 60), as críticas que parecem ser dirigidas diretamente a Deus nessas letras de Yupanqui não representam necessariamente "una actitud atea". Segundo o autor, o que se pretende questionar nessas composições é, na realidade, a poderosa aliança entre a Igreja e o Estado, o qual é representado neste caso pelas camadas que dominam sua vida política, econômica e social (o "patrón" bem identificado pelos versos). Tal relação culminaria com um afastamento do clero (e, simbolicamente, de Deus) da população comum. O que existe na composição, em consequência, é "una crítica a la que se considera una presencia incompleta de Dios en la tierra. Se supone con esto, que en todos los sitios donde hay pobreza es porque la mano de Dios está ausente" (GUERRERO, 1994, p. 60).

Frente a este posicionamento de confrontação com a institucionalidade eclesiástica católica, pareceria improvável que um membro do clero viesse a ser exaltado em versos identificados com esse viés artístico que ganhava corpo, simultaneamente, em diversos palcos latino-americanos. No entanto, foi precisamente o que ocorreu em Cruz de Luz, composição do uruguaio Daniel Viglietti elaborada em homenagem ao padre colombiano Camilo Torres. A história pessoal de Torres, contudo, ganhou notoriedade por seu caráter excepcional, o que ajuda a explicar a concepção de uma letra que o toma como personagem principal: o tributo prestado por Viglietti não se dá pela atuação do pároco junto à instituição da Igreja, mas, ao contrário, por haver rompido com ela e decidido militar na guerrilha do Exército de Libertação Nacional (ELN) de seu país, acabando por ser morto em 1966.

Em Cruz de Luz, Daniel Viglietti canta:

\title{
Lo mataron cuando iba \\ por su fusil, \\ Camilo Torres muere \\ para vivir.
}

Cuentan que tras la bala

se oyó una voz.

Era Dios que gritaba:

¡Revolución! 


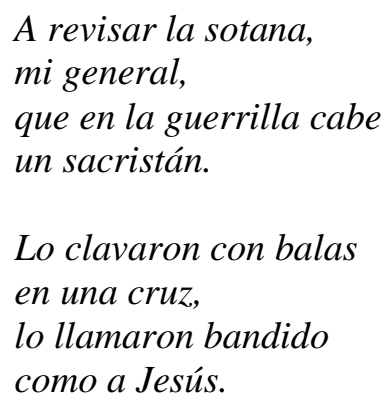

A canção de Viglietti é representativa da multiplicidade de posicionamentos quanto à religião demonstrada pelas composições de esquerda dessa época, como mencionamos acima: a Igreja, enquanto instituição, parece ser dispensável e sequer é citada nos versos do uruguaio, mas isso não necessariamente redunda em uma negação automática dos símbolos e narrativas do cristianismo cultuados pela maioria da população. Nesse exemplo, são evocadas a ressurreição e a cruz, Camilo Torres é comparado a Jesus Cristo e, inclusive, sugere-se que Deus clama pela Revolução que cobrou a vida do padre guerrilheiro. Ao subverter a lógica conservadora com que o clero costumava ser identificado, o sacerdote colombiano ganha lugar num discurso que, embora oposto ao catolicismo institucional, procura antes ressignificar os símbolos historicamente apropriados pela Igreja do que derrubá-los por completo.

De maneira geral, se as críticas à Igreja rapidamente se convertem em lugarcomum em muitas das produções desses artistas nos anos 1960, o mesmo não pode ser dito sobre a religiosidade e a fé como um todo. Mesmo um compositor como o chileno Víctor Jara, folclorista autor de letras ácidas como La luna siempre es muy linda ${ }^{4}$, e que chegou a abandonar o seminário na juventude por se desiludir com a clausura e o distanciamento clerical em relação aos problemas sociais do cotidiano ${ }^{5}$, admitiu o poder dessa linguagem. Em 1969, ao escrever a Plegaria a un labrador, uma prece cantada na qual pede a Deus que sua vontade de justiça social seja cumprida ("Líbranos de aquel que nos domina/ en la miseria,/ tráenos tu reino de justicia/ e igualdad"), Víctor Jara optou deliberadamente por inspirar seus versos nas orações do Padre-Nosso e da Ave Maria. Justificava a decisão apontando a penetração das crenças religiosas entre os chilenos humildes, a quem destinava sua mensagem:

En la Plegaria a un labrador ubico el rezo con la llamada, conozco a la mística de mi pueblo y sé que gran parte de él es demasiado apegado a creencias religiosas. Es por eso que hago esta combinación que es una bella forma de darse a entender por estos compañeros (KÓSICHEV, 1990, p. 98).

\footnotetext{
${ }^{4}$ Canção autobiográfica de 1962, La luna siempre es muy linda é um recorte de recordações da infância de Víctor Jara no campo e da pobreza de sua família, criticando a forma como a Igreja se valia da fé dos campesinos ao mesmo em tempo em que ignorava seus problemas, em versos como "las velas siempre encendidas/ hay que refugiarse en algo/ ¿de dónde sale el dinero/ para pagar la fe?" ou "al pobre tanto lo asustan/ para que trague todos sus dolores/ para que su miseria la cubra de imágenes".

${ }^{5}$ Cf. Jurado e Morales (2003, p. 32-33).
} 
A Plegaria de Víctor Jara venceu o Primer Festival de la Nueva Canción Chilena, evento de 1969 que deu nome ao movimento artístico. Mas há outra composição igualmente importante para a Nova Canção, assinada por Violeta Parra, que também exemplifica essa ambiguidade na forma de encarar a religião a partir de um viés politicamente engajado: "La Carta, de 1962, brinca com as expectativas do senso comum em seu último verso. Ao referir-se aos seus irmãos e à eventual perseguição que poderiam sofrer por suas ideologias de esquerda ${ }^{6}$, Violeta diz sobre eles: "los nueve son comunistas/ con el favor de mi Dios". Apesar de descrevê-los como comunistas (ainda que não filiados ao Partido), e, portanto, geralmente vistos como antirreligiosos, Parra se permitia fazer um paradoxal agradecimento a Deus pela orientação política de seus irmãos. Desta forma, novamente abria a possibilidade de manter um traço de fé religiosa mesmo distante da Igreja tradicional.

Em letras posteriores, tais como Miren como sonríen ("Miren como profanan/ las sacristías/ con pieles y sombreros/ de hipocresía") e Yo canto a la diferencia ("Ahí pasa el señor vicario/ con su palabra bendital ¿Podría su santidad/ oírme una palabrita?/ Los niños andan con hambrel les dan una medallital o bien una banderita"), as críticas de Violeta à Igreja voltariam a se manifestar.

\section{3) Porque los pobres no tienen: uma canção pioneira}

Se o tom questionador à Igreja seguiria presente em algumas canções de Violeta Parra até sua morte, é interessante voltar àquela que é considerada sua primeira composição autoral a abordar a questão de forma mais explícita: Porque los pobres no tienen, escrita no início da década de 60 e, curiosamente, jamais gravada na voz de Violeta. As primeiras versões editadas em disco foram cantadas por sua filha, Isabel Parra, que incluiu a música em seu primeiro LP como solista, lançado no Chile em $1966^{7}$.

O contexto em que o disco saiu se diferenciava sensivelmente daquele em que a música havia sido escrita, como veremos num momento posterior desse artigo. Nossa análise, portanto, procura focalizar a conjuntura na qual a letra a seguir foi elaborada, anterior à modernização vivida sobretudo a partir de meados dos anos 60, quando o disco de Isabel Parra é gravado e difundido no país ${ }^{8}$ :

\section{Porque los pobres no tienen adonde volver la vista,}

\footnotetext{
${ }^{6}$ La Carta foi literalmente escrita após Violeta receber uma carta contando da prisão de seu irmão Roberto por apoiar uma greve.

${ }^{7}$ O disco Isabel Parra, lançado pelo selo Demon em 1966, é o primeiro editado no Chile a incluir Porque los pobres no tienen. No entanto, Isabel chegou a gravar a canção anteriormente em duas ocasiões, para produções lançadas no estrangeiro: a primeira gravação data de 1962, em Berlim, e foi lançada em 1965 num disco intitulado Süd- und mittelamerikanische Volksmusik (Canções Populares Sul e CentroAmericanas). A segunda gravação foi realizada em 1963, em Paris, mas não veio a público até 1991 (cf. Francisco Luque, 2009).

${ }^{8}$ Ressalte-se, inclusive, que alguns versos cantados no LP se diferenciam daqueles escritos originalmente por Violeta Parra.
} 


\begin{abstract}
la vuelven hacia los cielos
con la esperanza infinita

de encontrar lo que a su hermano

en este mundo le quitan.
\end{abstract}

Palomita,

¡qué cosas tiene la vida!,

y zambita.

Porque los pobres no tienen

adonde volver la voz,

la vuelven hacia los cielos

buscando una confesión,

ya que su hermano no escucha

la voz de su corazón.

Porque los pobres no tienen

en este mundo esperanza,

se amparan en la otra vida

como a una justa balanza.

Por eso las procesiones,

las velas y las alabanzas.

De tiempos inmemoriales

que se ha inventado el infierno

para asustar a los pobres

con sus castigos eternos,

$y$ al pobre, que es inocente,

con su inocencia creyendo.

Y pa'seguir la mentira,

lo llama su confesor.

Le dice que Dios no quiere

ninguna revolución,

ni pliego ni sindicato,

que ofende su corazón.

Pela leitura dos versos acima, podemos considerar que a composição de "Porque los pobres no tienen" está dividida, de acordo com o tom de abordagem da temática, em duas partes principais. Nas três primeiras estrofes da canção ${ }^{9}$, iniciadas repetida e sugestivamente com o verso que também dá título à música, Violeta Parra refere-se sobretudo aos pobres e à sua fé. Ao destacar a falta de algo, descrevendo em seguida aquilo que eles não têm, são introduzidas as mensagens de abandono e desamparo que marcam este momento da canção. Nessas estrofes, o pobre aparece como alguém que não tem para onde dirigir sua vista e sua voz, sofrendo ainda com a falta de esperanças dentro do mundo terrenal. O consolo que poderia ser - e, na canção, é - buscado através da religiosidade, é procurado sem o intermédio da Igreja. Como argumenta Eni Orlandi (1987, p. 243), dentro do discurso religioso, a voz do padre é (como se fosse) a voz de

\footnotetext{
${ }^{9}$ Nas referências às estrofes, não consideraremos o estribilho "Palomita,/ ¡qué cosas tiene la vida!,/ y zambita" na contagem.
} 
Deus. Mas, na crítica de Violeta Parra, a voz apresentada pelo pregador está em desacordo com os anseios do pobre.

Ao iniciar suas frases com um "porque", a autora indica que tal desamparo realmente existiria, e procura desde logo estabelecer uma lógica dentro da qual são justificadas e explicadas as atitudes dos sujeitos descritos, os quais se voltam à fé para suprir as carências que se repetem na vida cotidiana. Deste modo, diante da ausência de instâncias terrenas e também de representantes da sociedade dispostos a receber e escutar suas demandas, a alternativa encontrada seria voltar-se para os céus (ou para a "outra vida", como diz a terceira estrofe), ato concretizado através da devoção. Essa mensagem é reiterada nos três versos iniciais de cada uma das três primeiras estrofes, cuja estrutura se assemelha notavelmente: "Porque los pobres no tienen/ adonde volver la vista/ la vuelven hacia los cielos" ( $1^{\mathrm{a}}$ estrofe); "Porque los pobres no tienen/ adonde volver la voz/ la vuelven hacia los cielos" ( $2^{\mathrm{a}}$ estrofe); "Porque los pobres no tienen/ en este mundo esperanza/ se amparan en la otra vida" ( $3^{\text {a }}$ estrofe).

Nessas três estrofes, o que se segue a partir do quarto verso é uma descrição do que se busca com o ato de dirigir aos céus os desejos e a exposição das necessidades rotineiras. Ao direcionar sua vista para a fé ( $1^{\mathrm{a}}$ estrofe), o pobre procura encontrar o que é negado ao seu hermano neste mundo e, pode-se argumentar, também a ele próprio. Ao dirigir sua voz para os céus ( $2^{\mathrm{a}}$ estrofe), pretende encontrar uma forma de expiar seu sofrimento, representado pelo peso dos pecados que sente haver cometido, uma vez que a composição fala na tentativa de encontrar uma confissão. Aqui, volta a aparecer a figura do hermano, mas já de maneira diferente: se antes o "irmão" em questão igualava-se ao pobre cuja história é contada, padecendo das mesmas carências, agora ele é um sujeito distinto, que o encara com um nítido distanciamento - e poderia ser identificado como o padre confessor -, pois não é capaz de escutar "la voz de su corazón".

A terceira estrofe repisa a ideia de refúgio da realidade, através da tentativa de confortar-se com a crença em uma outra vida. Os pobres, assim, "se amparan en la otra vida", considerando-a "como a una justa balanza". Desta maneira, veem nela uma justiça que não existe no mundo terreno, e que só seria possível após a morte. Para tanto, eles entenderiam como necessária a demonstração da fé por meio de manifestações de sua religiosidade, descritas na sequência dessa estrofe, como a participação em procissões, o acendimento de velas e os louvores em geral.

Note-se que Violeta Parra explica essas demonstrações de cristianismo sem fazer uma menção direta a qualquer filiação à Igreja, indicando que podem se tratar de uma busca autônoma e independente por amparo espiritual. Depois de dizer que os pobres se apoiam na outra vida perseguindo a esperança que não teriam nesta, ela justifica: "Por eso las procesiones/ las velas y las alabanzas". Essa tentativa de explicar a fé sem associá-la necessariamente às instituições da Igreja, uma constante em composições do período, como vimos, estaria relacionada com as próprias convicções religiosas de Violeta. Como argumenta Jorge Montealegre em seu ensaio biográfico sobre a folclorista: "Devota desde la religiosidad popular, como lo es en sus versos por padecimento [...]; [Violeta Parra] es irreverente y mordaz con la iglesia 
institucionalizada en la que reconoce la práctica hipócrita de um catolicismo clasista" (MONTEALEGRE, 2011, p. 57).

Outro aspecto a ser comentado na terceira estrofe é o que aparenta ser um esvaecimento das esperanças mencionadas em um momento anterior da composição. Enquanto na primeira estrofe se diz claramente que o pobre olha para o céu com "esperanza infinita", agora ela simplesmente não existiria: "Porque los pobres no tienen/ en este mundo esperanza". Mas essa repetição do termo, dessa vez para negá-lo, não é uma contradição em relação ao que se disse anteriormente: ela vem para reforçar a oposição entre céu e terra que a música procura demarcar. A esperança apenas não existiria neste mundo, mas já não é invalidada quando o indivíduo busca o amparo divino para seu sofrimento.

A fé descrita até este momento da música, como vimos, não dependeria da instituição Igreja. É uma devoção que, embora cristã, estaria livre de intermediações. No entanto, no que poderíamos considerar como a segunda parte da canção, formada por suas duas últimas estrofes, a Igreja finalmente aparece. E, se antes o pobre era descrito como alguém capaz de buscar uma relação mais direta com o mundo espiritual apenas por voltar-se para o céu e manifestar sua crença, agora ele está sujeito às narrativas do catolicismo.

$\mathrm{Na}$ quinta e última estrofe, que analisaremos posteriormente, a Igreja aparecerá de forma clara como intermediadora (através da figura do padre confessor) do elo entre os fiéis e seu Deus, enquanto na quarta estrofe ela surge implicitamente com a menção de seus discursos sobre pecado e penitência, como a ideia de inferno recordada pela canção: "De tiempos inmemoriales/ que se ha inventado el infierno/ para asustar a los pobres/ con sus castigos eternos". Se não foi a Igreja que criou o conceito de inferno, presente na Bíblia e em outras crenças religiosas - inclusive fora do cristianismo -, ela historicamente ajudou a difundir a simbologia comumente relacionada a esse padecimento, consolidando o temor cristão às penas eternas.

Quando Violeta Parra refere-se à invenção do inferno, desde tempos imemoriais, para assustar os pobres, não necessariamente se refere aos textos bíblicos. Considerando o teor da canção, ela pode estar dirigindo sua crítica à construção tradicional que prega o arrependimento e o temor pelo desrespeito a determinadas doutrinas. Na sequência da quarta estrofe, Violeta volta a falar dos pobres, agora como "inocentes" - em mais de um sentido: "y al pobre, que es inocente,/ con su inocencia creyendo". No sentido mais evidente, o pobre pode ser considerado inocente pela ingenuidade que se percebe na crença e no receio quanto à possibilidade de castigos por seus atos, mas também poderia sê-lo por não ter motivos para temer uma pena tão pesada.

Na quinta e última estrofe, fica mais evidente o contraponto entre a religiosidade popular e a institucionalidade eclesiástica:

Y pa'seguir la mentira,

lo llama su confesor.

Le dice que Dios no quiere

ninguna revolución,

ni pliego ni sindicato,

que ofende su corazón. 
Nessa estrofe, a autora reforça a ideia da Igreja ligada aos setores dominantes da sociedade, exploradores dos pobres a quem Violeta Parra tenta dar voz, setores que se sentiriam ameaçados pelas reivindicações populares e contariam com a religião institucionalizada para defender seus interesses. Ao buscar o conforto através da confissão mediada pela Igreja, o pobre se depararia com um discurso desmobilizador dos movimentos sociais.

Percebe-se ainda uma inter-relação com a segunda estrofe, ao final da qual se lê que os pobres dirigem sua voz diretamente aos céus, buscando uma confissão "ya que su hermano no escuchal la voz de su corazón". Como argumentamos mais acima, o hermano em questão poderia ser o padre confessor, que não compreenderia as aflições do pobre. O confessor retorna na quinta estrofe com a pretensão de falar em nome de outro corazón - o coração divino -, que se sentiria ofendido pelas revoluções e sindicatos. Dessa maneira, volta a ser ressaltado o distanciamento da instituição católica em relação aos problemas sociais e, simultaneamente, sua aproximação com setores conservadores e patronais da sociedade.

Escrevendo sobre esta canção, Bernardo Guerrero argumenta:

Dos ideas nos parecen relevantes en este tema. Uno, tiene que ver con la concepción de la religión como enajenación de la realidad; y dos, asociar al clero a las clases dominantes que describen a Dios como un ente que no le agradan los problemas del pueblo, menos aún si éste aspira a la organización para superar sus problemas (GUERRERO, 1994, p. 60).

Retomando alguns postulados de Louis Althusser ${ }^{10}$, Eni Orlandi comenta que, embora exista certa possibilidade para diferentes interpretações e leituras da palavra de Deus, essa interpretação é regulada - e, além de certo limite, pode ser considerada uma transgressão: "no cristianismo, enquanto religião institucional, a interpretação própria é a da Igreja" (ORLANDI, 1987, p. 246). Escrevendo sua crítica num momento em que alguns setores da Igreja ainda eram comumente associados às camadas dominantes da sociedade, Violeta identifica o posicionamento do "padre" com uma tendência a fechar as portas para práticas e discursos que contrariem os interesses das oligarquias do país. A interpretação oficial oferecida seria, então, que a Deus não agradam revoluções ou sindicatos.

Assim, a Igreja por fim aparece de forma clara no discurso da compositora. $\mathrm{Na}$ concepção que Violeta Parra atribui à Igreja, o pobre não deveria lutar por uma vida melhor na terra, porque os meios de fazer isso (a revolução, as cartas de reivindicações e os sindicatos) desagradariam ao Senhor, condenando o fiel a uma eternidade de sofrimentos. Segundo Adilson Citelli (2002, p. 48), como a voz de Deus "plasmará todas as outras vozes, inclusive a daquele que fala em seu nome", o discurso do padre "se constrói como verdade não sua, mas do outro, aquele que, por ser considerado determinação de todas as coisas, engloba todas as falas do rebanho", portanto, não poderia ser questionado. Representada pelo padre confessor, que diz ao pobre o que

\footnotetext{
${ }^{10}$ Cf. Althusser (1974, p. 105-114).
} 
Deus "desaprova", a Igreja do discurso construído por Violeta Parra parece desejar o monopólio sobre a interpretação da palavra divina, fazendo-o com um viés conservador.

Em outro contexto, porém, quando tendências progressistas fossem mais fortes dentro da Igreja no Chile, o discurso desta e a interpretação da palavra divina oferecida aos fiéis poderiam ser distintos. Eni Orlandi ressalta que o discurso se constitui na relação entre linguagem e exterioridade, relacionando-se, pois, ao contexto de enunciação e ao contexto histórico-social. Convém então recordar que, em 1966, no momento em que o disco de Isabel Parra incluindo Porque los pobres no tienen chegou às rádios, os questionamentos elaborados por Violeta encontravam uma conjuntura possivelmente não imaginada pela autora no momento da composição.

Entre 1964 e 1970, a presidência chilena foi ocupada por Eduardo Frei Montalva, o primeiro membro do Partido Democrata Cristão (PDC) a chegar ao cargo. O governo do PDC era repudiado pelo que a esquerda tradicional considerava uma demora excessiva nas mudanças sociais que dizia promover, bem como pela repressão violenta a algumas manifestações de oposição e movimentos de pobladores e grevistas, sobretudo na fase final da administração de Frei ${ }^{11}$. Mas, embora a administração democrata-cristã desagradasse aos partidários de esquerda, sua plataforma reformista era indubitavelmente distinta do conservadorismo que governara o Chile até pouco tempo antes. Mais do que isso, o PDC contava com franco apoio da Igreja Católica, o que era sintomático da abertura de alguns setores do clero a posicionamentos mais progressistas. Com efeito, um dos atos simbólicos que iniciou a reforma agrária no Chile foi a doação, pela diocese de Talca, de algumas terras aos camponeses que lá trabalhavam.

Como comenta Jesús Manuel Martínez:

La revolución que encumbró a Eduardo Frei Montalva y lo propulsó a una competición a muerte (literalmente a muerte) con [Salvador] Allende no fue tanto la bulliciosa y efimera "revolución en libertad" de su victoriosa campaña electoral de 1964, sino más bien la revolución silenciosa y profunda que incubó de forma poco predecible en el seno de la Iglesia Católica chilena. Esta institución oligárquica y reaccionaria, sumisa a un Partido Conservador situado en el extremo derecho del arco parlamentario, irrumpió en los años 60 del siglo XX como una fuerza política, social y popular moderna, rompedora, ilustrada, con capacidad para jugar a sus anchas en todos los espacios del tablero: en la derecha, en la izquierda y en el centro (MARTÍNEZ, 2009, p. 243).

A "revolución en libertad" de Frei, um termo cunhado para se opor à revolução "marxista" e "sem liberdade" que se queria imputar a um eventual governo do socialista Salvador Allende, defendia pontos antes não mencionados fora das fileiras comunistas e socialistas, como a reforma agrária e a nacionalização de parte da mineração do cobre, mantida até então por empresas estrangeiras.

\footnotetext{
${ }^{11}$ Um dos episódios que mais manchou a imagem do governo Frei ocorreu em 9 de março de 1969, no penúltimo ano da administração democrata-cristã. Uma ocupação de terreno pacífica realizada por pobladores arrabaldes de Puerto Montt, no sul do país, foi violentamente reprimida pelas forças policiais, que deixaram um saldo de dez pessoas mortas. Víctor Jara, um dos nomes mais destacados da Nova Canção Chilena, compôs "Preguntas por Puerto Montt", acusando a responsabilidade do governo no episódio.
} 
Deste modo, ao analisar a composição de Violeta Parra, deve-se considerar que a conjuntura na qual a letra foi escrita se distinguia sensivelmente daquela na qual a versão gravada por Isabel Parra chegou ao público chileno. Escrevendo em 1962, Violeta ainda compõe em um contexto marcado por posições mais conservadoras de alguns setores da Igreja no Chile, associados às camadas dominantes da sociedade. Esse antigo posicionamento - e as percepções artísticas sobre ele - começaria a se modificar ao longo daquela década, levando a uma aproximação com os movimentos sociais, proximidade esta que se acentuaria ainda mais durante a ditadura de Pinochet, estabelecida em 1973.

\section{4) Considerações finais}

Porque los pobres no tienen, primeira composição de Violeta Parra a questionar explicitamente a Igreja, seria sucedida por outras produções artísticas de temática semelhante, tanto da própria autora quanto de artistas contemporâneos, dentro e fora do Chile. Mesmo num contexto em que setores do clero ensaiavam uma modernização, o passado de alinhamento às classes dominantes ainda fez com que letras questionadoras à Igreja seguissem aparecendo. Conforme a década de 60 avançou, no entanto, essa crítica parece ter arrefecido. Bernardo Guerrero lembra que o cancioneiro que se fez conscientemente ou não - portador de valores da esquerda latino-americana teve, em seus inícios, "un profundo anticlericalismo que con el tiempo irá desapareciendo" (GUERRERO, 1994, p. 55).

Como vimos, as manifestações artísticas com teor de crítica à Igreja não eram exatamente novas: encontravam raízes na tradição popular, a qual guardava versos pícaros ou cáusticos que buscavam indagar sobre o aparente distanciamento dos padres em relação aos problemas e dificuldades cotidianos. O que ocorreu na época de Violeta Parra, Atahualpa Yupanqui e outros compositores cujos versos se destacaram nessa crítica foi a possibilidade de acesso a meios novos de difusão para esse tipo de música, com a gravação de discos - ainda que por selos independentes - e a exposição, embora limitada, em rádios. Se houve um número maior de canções com esse teor durante as décadas de 1950 e 1960, isso também se relacionava com uma conjuntura mais ampla, num momento em que a própria sociedade estava questionando de forma mais enfática o papel da Igreja, o que levou a própria instituição católica a procurar respostas e iniciar reformas importantes.

As abordagens nas produções artísticas do período em relação à religião eram variadas, mas também havia multiplicidade nos posicionamentos da Igreja, ela mesma fendida internamente por tendências ideológicas distintas. Essa situação era presente em vários países latino-americanos e igualmente notável no Chile. Ali, a instituição católica tinha larga tradição de colaboração com grupos conservadores - o que gerou grande parte das críticas produzidas por autores da Nova Canção Chilena - mas, a partir da década de 1960, veria setores seus se aproximando cada vez mais de posturas progressistas, fosse em relação a políticas como reforma agrária ou, após 1973, no apoio oferecido aos perseguidos políticos pela ditadura de Augusto Pinochet. 


\section{Referências}

ADVIS, Luis. Historia y Características de la Nueva Canción Chilena. In: ADVIS, Luis et al. Clásicos de la Música Popular Chilena (1960-1973), v. II: Raíz Folklórica. 2.ed. Santiago de Chile: Sociedad Chilena del Derecho de Autor, 2012.

ALTHUSSER, Louis. Ideologia e Aparelhos Ideológicos do Estado. Lisboa: Presença, 1974.

BARRAZA, Fernando. La Nueva Canción Chilena. Santiago de Chile: Quimantú, 1972. Disponível em <http://www.abacq.net/imagineria/ncch2.htm> Acesso em: 5 jul. 2014.

BILBAO, Francisco. Sociabilidad Chilena. El Crepúsculo, Santiago de Chile, n. 2, t. 2, p. 57-90, jun. 1844.

CITELLI, Adilson. Linguagem e persuasão. 15.ed. São Paulo: Ática, 2002.

GARCÍA, Marisol. "Violeta Parra, al centro de la injusticia”. In: Canción valiente: 1960-1989 - Tres décadas de canto social y político en Chile. Santiago de Chile: Ediciones B, 2013, p. 27-44.

GUERRERO JIMÉNEZ, Bernardo. "Religión y canción de protesta en América Latina; un ensayo de interpretación". Revista de Ciencias Sociales, Universidad Arturo Prat, n. 4, p. 55-64, 1994.

KÓSICHEV, Leonard. La guitarra y el poncho de Víctor Jara. Moscou: Progreso, 1990.

LIBANIO, João Batista. Concílio Vaticano II. Em busca de uma primeira compreensão. São Paulo: Loyola, 2005.

LUQUE, Francisco. Violeta Parra: El disco ausente. Cancioneros: diario digital de música de autor, 12 nov. 2009. Disponível em < http://www.cancioneros.com/co/890/2/violeta-parra-el-disco-ausente-por-franciscoluque> Acesso em 18 jul. 2014.

MARTÍNEZ, Jesús Manuel. Salvador Allende. El hombre que abría las alamedas. Santiago de Chile: Catalonia, 2009.

MONTEALEGRE, Jorge. Violeta Parra. Instantes fecundos, visiones, retazos de memoria. Santiago de Chile: Universidad de Santiago de Chile, 2011.

ORLANDI, Eni Pulcinelli. A linguagem e seu funcionamento. As formas do discurso. 2.ed. Campinas: Pontes, 1987.

PARRA, Ángel. Violeta se fue a los cielos. 5.ed. Santiago de Chile: Catalonia, 2012.

SALINAS CAMPOS, Maximiliano. Canto a lo divino y religión popular en Chile hacia 1900. 2.ed. Santiago de Chile: LOM, 2005. 
SOUZA, Ney de. Contexto e desenvolvimento do Concílio Vaticano II. Revista de Teologia e Cultura, São Paulo, n. 2, p. 1-36, out.-dez. 2005. Disponível em < http://ciberteologia.paulinas.org.br/ciberteologia/wpcontent/uploads/2009/05/contexto_desenvolvimento.pdf> Acesso em 12 jul. 2014. 